\title{
Colonic Diverticulum
}

National Cancer Institute

\section{Source}

National Cancer Institute. Colonic Diverticulum. NCI Thesaurus. Code C34550.

A pouch or sac-like protrusion in the colonic wall. 